\title{
Norcantharidin Induces HL-60 Cells Apoptosis In Vitro
}

\author{
You-Ming Jiang, ${ }^{1}$ Zhen-Zhi Meng, ${ }^{1}$ Guang-Xin Yue, ${ }^{2}$ and Jia-Xu Chen ${ }^{1,3}$ \\ ${ }^{1}$ School of Pre-Clinical Medicine, Beijing University of Chinese Medicine, Beijing 100029, China \\ ${ }^{2}$ Institute of Basic Theory of TCM, China Academy of Chinese Medical Sciences, P.O. Box 83, Beijing 100700, China \\ ${ }^{3}$ Department of Basic Theory in Chinese Medicine, Henan University of Traditional Chinese Medicine, Zhengzhou 450008, China
}

Correspondence should be addressed to Jia-Xu Chen, chenjiaxu@hotmail.com

Received 29 February 2012; Revised 3 May 2012; Accepted 3 May 2012

Academic Editor: Vincenzo De Feo

Copyright () 2012 You-Ming Jiang et al. This is an open access article distributed under the Creative Commons Attribution License, which permits unrestricted use, distribution, and reproduction in any medium, provided the original work is properly cited.

\begin{abstract}
Norcantharidin (NCTD) is the demethylated form of cantharidin, which is the active substance of mylabris, and is known to have anticancer potentials. The aim of this paper was to assess the apoptosis-inducing effect of NCTD on HL-60 cells. Methods. The effects of NCTD were detected by flow cytometer on the cell toxicity, cell cycle, and apoptosis of HL-60 cells cultured in vitro. Results. After 48-hour treatment with NCTD, the growth of HL-60 cells was inhibited significantly. The summit of apoptosis appeared after 24 hours. The percentage of the cells in $\mathrm{G}_{1}$ phase decreased and then increased in $S$ and $\mathrm{G}_{2}+\mathrm{M}$ phase, while the $\mathrm{S}$ and $G_{2}+M$ phases were blocked after treatment with 5,10 , and $50 \mu \mathrm{mol} / \mathrm{L}$ NCTD for 24 hours. Conclusions. NCTD can induce the apoptosis of HL-60 cells and inhibit the fissiparism, and the domino effect was obviously correlated with the time and dosage.
\end{abstract}

\section{Introduction}

Mylabris, the polypide of Mylabris phalerata Pall or Mylabris cichorii Linnaeus, characterized by being cold in nature, acrid in flavor, and toxic, has the effect of removing toxic substance for cellulites, breaking blood stasis, and dispersing accumulation. It has been showed that cantharidin is the main ingredient for anticarcinogenic effect of mylabris, chemical structure of which is exo-1,2-syn-dimethyl-3,6oxidohydrophthalic anhydride. Norcantharidin (NCTD) is the demethylated form of cantharidin, which is the active substance of mylabris, and is known to have anticancer potentials. NCTD is a kind of new-type anticancer drug with the effect of increasing white cells. It was synthesized with furan and maleic anhydride through Diels-Alder reaction [1] and was currently used as an anticancer drug in China. Many experiments including our previous study [2] have demonstrated that NCTD can inhibit the growth of tumor cells in vitro and in vivo [3-9]. However, the exact anticancer mechanism of NCTD on human cancer cells remains poorly understood. In the present study, flow cytometer and cytomorphology staining were used to study the effect of NCTD on apoptosis and cell cycle of HL-60 cells.

\section{Materials and Methods}

2.1. Cell Strain. HL-60 cells were cultivated in pure RPMI1640 (purchased from GBICO), placed in a temperaturecontrolled $\mathrm{CO}_{2}$ incubator $\left(37^{\circ} \mathrm{C}\right)$, transfer of culture one time every 2-3 days. Experiment started when cells entered exponential growth stage, the best state.

2.2. Drugs and Agent. Calf serum was provided by Institute of Hematologic Disease in Tianjin affiliated to Chinese Academy of Medical Sciences; NCTD was purchased from the Forth Pharmaceutical Factory in Beijing and was dissolved by DSMO. RNA enzyme was purchased from Huamei Company, the concentration of which used in this experiment was $0.02 \mathrm{~g} / \mathrm{L}$. Propidium iodide (PI) (Sigma Company), the concentration of which used in this experiment was $0.05 \mathrm{~g} / \mathrm{L}$.

2.3. Flow Cytometer. Fluorescence-activated cell sorter, being manufactured by USA Becton Dickinson Company, type of 420, was provided by Institute of Basic Theory, China Academy of TCM. 


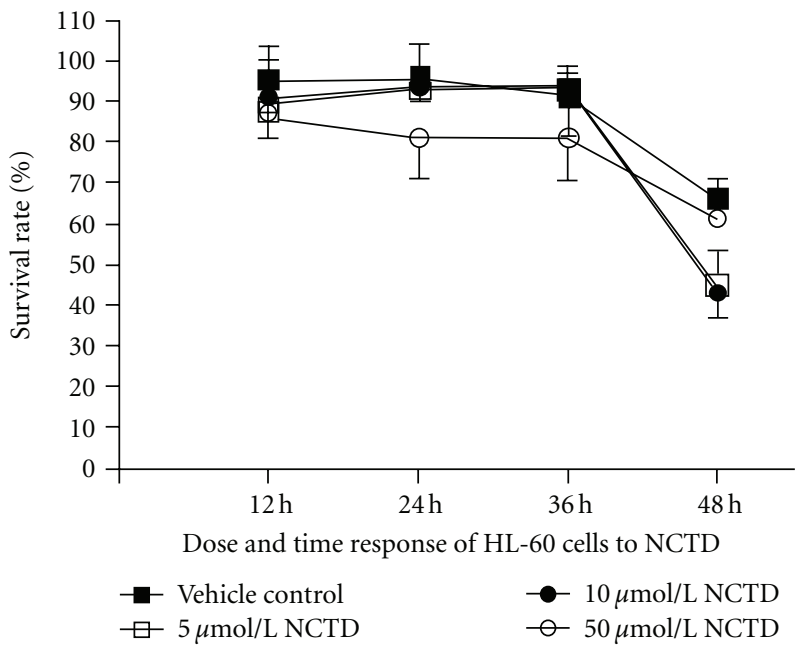

Figure 1: Cytotoxic effect of NCTD on HL-60 cells.

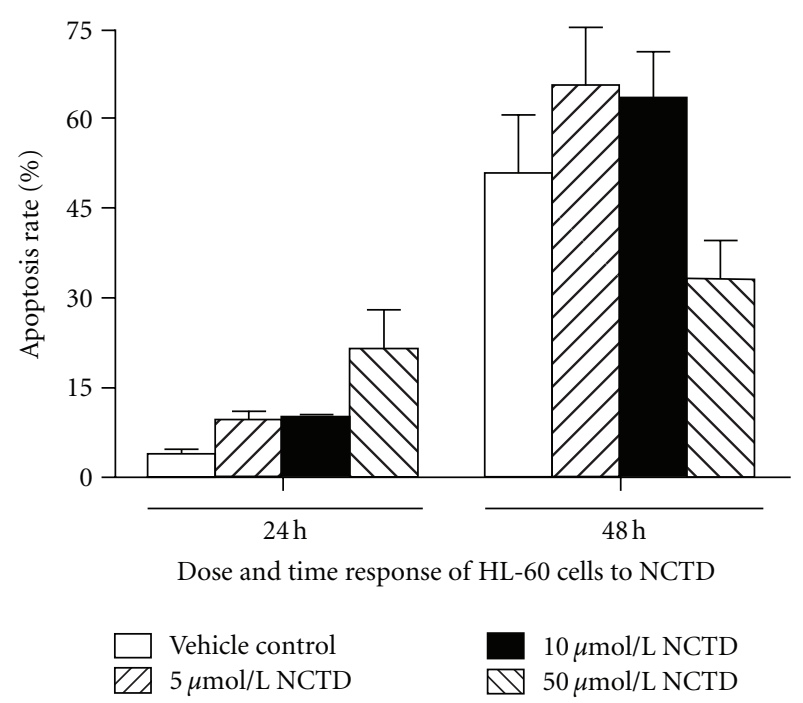

Figure 2: Effect of NCTD on HL-60 cells apoptosis.

2.4. Experiment of Dose and Time Response on HL-60 Cells by NCTD. Cell concentration was adjusted into $5 \times 10^{8} / \mathrm{L}$ when HL-60 cells were at the logarithmic increasing phase; then the cells were inoculated on 12 -well plates. Each well added $1 \mathrm{~mL}$ cell suspension and $3 \mathrm{~mL}$ RPMI-1640 containing 10\% calf serum, then added NCTD (the final concentrations were $5 \mu \mathrm{mol} / \mathrm{L}, 10 \mu \mathrm{mol} / \mathrm{L}, 50 \mu \mathrm{mol} / \mathrm{L}$, resp.), and DSMO as control group; each group had 3 parallel wells. Specimens were collected at $24 \mathrm{~h}, 48 \mathrm{~h}$ after the cell suspension was cultured in temperature-controlled incubator $\left(37^{\circ} \mathrm{C}, 0.05 \mathrm{CO}_{2}\right)$. Adding $200 \mu \mathrm{L}$ cell suspension into $100 \mu \mathrm{L} 1.8 \% \mathrm{NaCl}$ and $100 \mu \mathrm{L}$ $4 \%$ trypan blue stock solution to stain. Stained specimens were put into centrifugal machine for $1 \mathrm{~min}$ at $1000 \mathrm{r} / \mathrm{min}$, sucking the supernatant. The supernatant was washed by PBS ( $\mathrm{pH} 7.4,0.05 \mathrm{~mol} / \mathrm{L}$ ) two times and centrifuged for $1 \mathrm{~min}$ at $1000 \mathrm{r} / \mathrm{min}$ to count the alive cells and dead cells

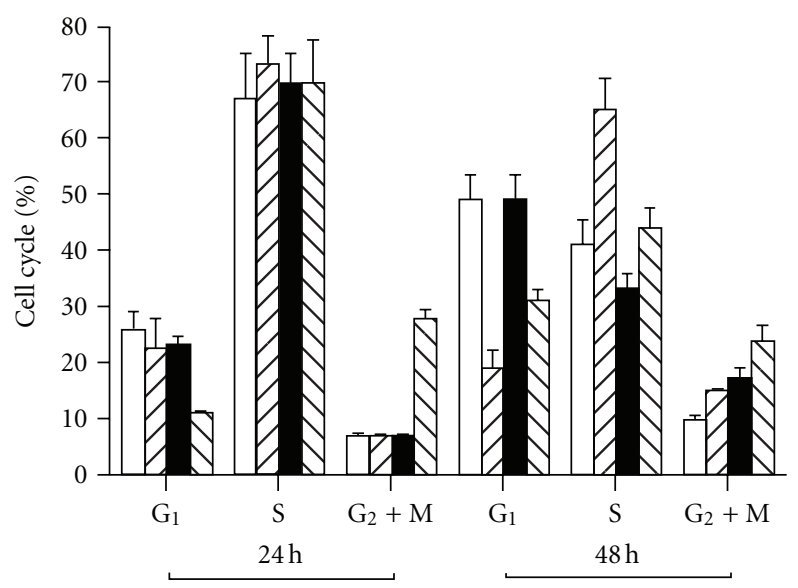

Effects of NCTD on cell cycle of HL-60 cells

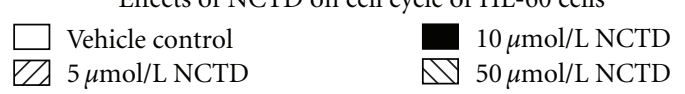

Figure 3: Effects of NCTD on HL-60 cell cycle.

under the invert microscope after the colorless supernatant was dropped on slide.

2.5. Experiment of Dose and Time Response on HL-60 Cells Apoptosis and Cell Cycle by NCTD. The concentration and action time of NCTD were the same as mentioned above. To collect cells after medication treatment, wash the cells with PBS not containing $\mathrm{Ca}^{2+}, \mathrm{Mg}^{2+}$ and centrifuge them for $5 \mathrm{~min}$ at $800 \mathrm{r} / \mathrm{min}$ twice, respectively. Then use syringe with TB pinhead to infuse cells precipitation into $70 \%$ alcohol $\left(4^{\circ} \mathrm{C}\right)$, shake until cells homogeneous dispersion, and fix the cells more than $18 \mathrm{~h}$. Concentration of cells was adjusted into $1 \times 10^{9} / \mathrm{L}$ after being centrifuged and washed. $500 \mu \mathrm{L}$ cell sap were lucifuge strained with $50 \mu \mathrm{L} 0.1 \%$ PI $(50 \mathrm{mg} / \mathrm{L}$ Propidium iodide, $0.1 \%$ Sodium-cit-rate, $0.1 \%$ triton $\mathrm{X}-100$ ) for $30 \mathrm{~min}$. Specimen was filtered with 400 holes net, exciting wavelength was set at $488 \mathrm{~nm}$, and blocking filter was $585 \mathrm{~nm}$. Photomultiplier tube and multichannel pulse analyzer were used to show apoptosis scatterplot. Flow cytometer analysis showed that near diploid cell mass peak appeared at the left of $G_{1}$ phase during cell apoptosis. Flow cytometer was used to determine the change of percentage of cell at $G_{1}$ phase, $S$ phase, and $\mathrm{G}_{2}+\mathrm{M}$ phase. Each group had $1 \times 10^{6}$ cells and 3 parallel wells.

2.6. Observation on Cytomorphology of HL-60 Cells after NCTD. The apoptotic morphology was observed by using staining reagent Wright-Giemsa. Collected HL-60 cells treated with NCTD at $1000 \mathrm{r} / \mathrm{min}$ for $5 \mathrm{~min}$ used PBS to rinse the collected cells one time. Collected cells were then resuspended in PBS and dropped on slide. Collected cells were fixed in Colonial spirit for 2-3 min after air drying, then open-air drying. Collected cells were stained in Giemsa stain. The stained cells were separated according to color in $95 \%$ alcohol for $30 \mathrm{~s}$ and dehydrated in absolute alcohol for 10$30 \mathrm{~s}$, cleared in dimethyl benzene, and enveloped with neutral gum. Cellular shape was observed and photographed under type 2 Leitz-ORTHOLUX light microscope (German). 

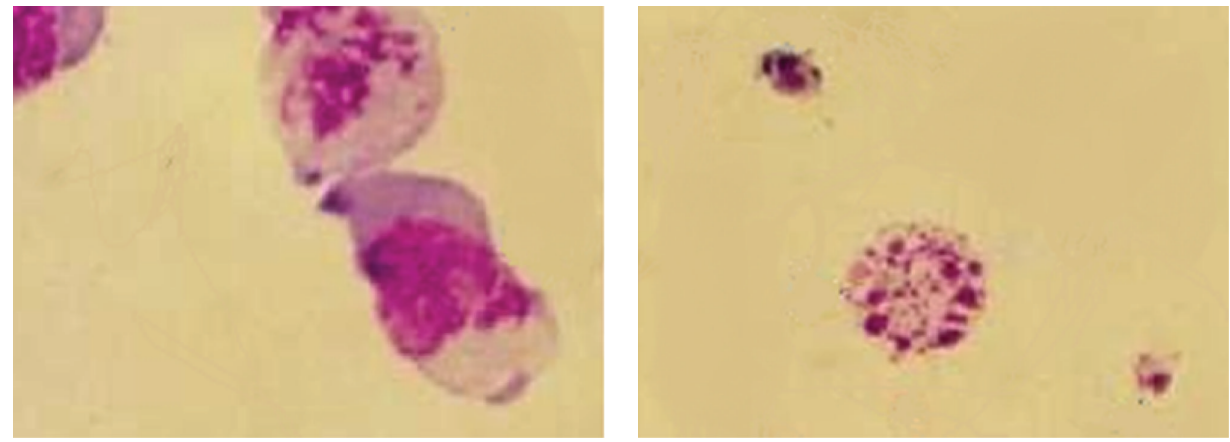

Figure 4: Cytomorphology of HL-60 cells after NCTD treatment $(\times 500)$.

2.7. Statistical Method. Data were analyzed by analysis of variance (ANOVA) followed by post hoc $t$ tests for comparisons between groups. Significance was accepted as $P<0.05$. Data are expressed as mean \pm standard deviation $(\mathrm{SD})$.

\section{Results}

3.1. Dose and Time Response on HL-60 Cells by NCTD. Trypan blue staining showed that the cytotoxic effect of NCTD on HL-60 cells increased with increase of time $(P<$ $0.01)$; survival rate of HL-60 cells decreased with increase of the concentration of NCTD $(P<0.05)$. Results showed that cytotoxic effect of NCTD on HL-60 cells was time and dose concentration response (Figure 1).

3.2. Dose and Time Response on HL-60 Cells Apoptosis by NCTD. Apoptosis of HL-60 appeared at $48 \mathrm{~h}(P<0.01)$. Apoptosis of HL- 60 induced by $5 \mu \mathrm{mol} / \mathrm{L}$ NCTD for $48 \mathrm{~h}$ was more apparent than those induced by other concentrations and also was time dependent. Apoptosis of HL-60 induced by $50 \mu \mathrm{mol} / \mathrm{L} \mathrm{NCTD}$ for $24 \mathrm{~h}$ was obvious (Figure 2 ).

3.3. Effects of NCTD on Cell Cycle of HL-60 Cells. Compared with blank control group, the percentages of HL-60 cells of $\mathrm{G}_{1}$ phase decrease after being treated by NCTD, while the percentages of HL-60 cells of $S$ phase and $G_{1}+M$ phase increased, the cell cycle was dramatically arrested at $\mathrm{G}_{2} / \mathrm{M}$ phase $(P<0.01)$. Effect of NCTD on HL-60 cells cycle was specially obvious with $50 \mu \mathrm{mol} / \mathrm{L}$ for $24 \mathrm{~h}$ and $48 \mathrm{~h}$ (Figure 3 ).

\subsection{Change of Cytomorphology of HL-60 Cells after NCTD} Treatment. Under inverted microscope, the HL-60 cells growth was round. After treatment with NCTD, the cell growth was inhibited, the growth velocity decreased, and the cell changed from round into ellipse, horseshoe shape, gradually. There were several ecthyma on edge of cell membrane, the cell clarity decreased apparently. Above phenomena became more obvious with the increase of the concentration of NCTD. Wright-Giemsa staining showed that apparent change of morphology appeared after treating with different concentrations of NCTD for $24 \mathrm{~h}$. Its expression was that the chromosome movement was abnormal at mitosis anaphase, nucleoplasm condensed into one or several big boluses, and cell nucleus split into shivers; thus ganoid apoptotic bodies encapsulated by cell membrane appeared to be intracellular (Figure 4 represents apoptosis cell and/or apoptotic body; left: $5 \mu \mathrm{mol} / \mathrm{L}$ NCTD treatment group; right: $50 \mu \mathrm{mol} / \mathrm{L}$ NCTD treatment group).

\section{Discussion}

The development of tumor is closely related to apoptosis. An important foundation of tumor development is reinforcement of cell multiplication or apoptosis blocking or multiplication and apoptosis reinforcement, but the reinforcement of multiplication exceeded that of apoptosis significantly. In recent years, it has been paid attention to apoptosis induced by Chinese materia medica at home and abroad [10]. It has been proved that lots of anticancer drug originated from Chinese materia medica such as taxol [11], camptothecin, teniposide, harringtonine [12], and trichosanthin [13] can induce tumor cell apoptosis.

Mylabris, characterized by being acrid in flavor, and cold in nature, is toxiferous; it should be processed before being used as decoction. Much attention has been attached to study on curative feasibility of toxiferous Chinese crude drug by the exploitation of its so-called function of fight fire with fire. Whether the mechanism of toxiferous Chinese crude drug is related to inducing apoptosis has been indefinite yet.

This study showed that the depressant effect of NCTD on HL-60 cells was apparent and had time and dose effect response. Flow cytometer showed that HL-60 cells appeared as apoptosis after treatment with $5 \mu \mathrm{mol} / \mathrm{L}, 10 \mu \mathrm{mol} / \mathrm{L}$, $50 \mu \mathrm{mol} / \mathrm{L} \mathrm{NCTD}$ for $24 \mathrm{~h}$ and $48 \mathrm{~h}$, and the effect of NCTD on HL-60 cells was dose dependent. After treating by NCTD, the percentage of HL- 60 cells decreased at $G_{1}$ phase, the percentage at $S$ phase and $\mathrm{G}_{2} / \mathrm{M}$ phase increased, and the cell cycle was dramatically arrested at $\mathrm{G}_{2} / \mathrm{M}$ phase and $\mathrm{S}$ phase. It indicated that NCTD could inhibit the DNA synthesis of HL60 cell at S phase obviously, interfere with karyokinesia, and thus, restrain the proliferation of tumor cells. In conclusion, NCTD can inhibit the growth of HL-60 cells by interfering with cell proliferation and inducing apoptosis. This has been proved by morphology staining, and its mechanism needs further investigation. 


\section{Acknowledgment}

This work was supported by Program for Innovative Research Team in Beijing University of Chinese Medicine (2011CXTD-07).

\section{References}

[1] B. J. Cao and J. Z. Wang, "Improvement on synthesis of norcantharidin,” Tianjin Pharmacy, vol. 7, no. 2, pp. 35-36, 1995.

[2] J. X. Chen, X. L. Liu, and Y. Liu, "Influence of norcantharidin on apoptosis of K562," China Journal of Traditional Chinese Medicine and Pharmacy, vol. 15, no. 2, pp. 21-23, 2000.

[3] W. W. An, X. F. Gong, M. W. Wang, S. I. Tashiro, S. Onodera, and T. Ikejima, "Norcantharidin induces apoptosis in HeLa cells through caspase, MAPK, and mitochondrial pathways," Acta Pharmacologica Sinica, vol. 25, no. 11, pp. 1502-1508, 2004.

[4] W. W. An, M. W. Wang, S. I. Tashiro, S. Onodera, and T. Ikejima, "Norcantharidin induces human melanoma A375-S2 cell apoptosis through mitochondrial and caspase pathways," Journal of Korean Medical Science, vol. 19, no. 4, pp. 560-566, 2004.

[5] Y. J. Chen, C. J. Shieh, T. H. Tsai et al., "Inhibitory effect of norcantharidin, a derivative compound from blister beetles, on tumor invasion and metastasis in CT28 colorectal adenocarcinoma cells," Anti-Cancer Drugs, vol. 16, no. 3, pp. 293299, 2005.

[6] Y. Z. Fan, J. Y. Fu, Z. M. Zhao, and C. Q. Chen, "Effect of norcantharidin on proliferation and invasion of human gallbladder carcinoma GBC-SD cells," World Journal of Gastroenterology, vol. 11, no. 16, pp. 2431-2437, 2005.

[7] S. H. Kok, S. J. Cheng, C. Y. Hong et al., "Norcantharidininduced apoptosis in oral cancer cells is associated with an increase of proapoptotic to antiapoptotic protein ratio," Cancer Letters, vol. 217, no. 1, pp. 43-52, 2005.

[8] J. L. Li, Y. C. Cai, X. H. Liu, and L. J. Xian, "Norcantharidin inhibits DNA replication and induces apoptosis with the cleavage of initiation protein Cdc6 in HL-60 cells," AntiCancer Drugs, vol. 17, no. 3, pp. 307-314, 2006.

[9] H. F. Liao, S. L. Su, Y. J. Chen, C. H. Chou, and C. D. Kuo, "Norcantharidin preferentially induces apoptosis in human leukemic Jurkat cells without affecting viability of normal blood mononuclear cells," Food and Chemical Toxicology, vol. 45, no. 9, pp. 1678-1687, 2007.

[10] Z. H. Zhou, "Research progress on chinese materia medica induces tumor cell apoptosis," Foreign Medical Science, vol. 20, no. 3, pp. 3-6, 1988.

[11] L. Milas, N. R. Hunter, B. Kurdoglu et al., "Kinetics of mitotic arrest and apoptosis in murine mammary and ovarian tumors treated with taxol," Cancer Chemotherapy and Pharmacology, vol. 35, no. 4, pp. 297-303, 1995.

[12] M. Fang, H. Q. Zhang, S. B. Xue et al., "Harringtonine induces HL-60 cells apoptosis," Chinese Science Bulletin, vol. 39, no. 12, pp. 1125-1129, 1994.

[13] L. Bi, H. Li, and Y. Zhang, "Effect of trichosanthin of cell cycle and apoptosis of murine melanoma cells," Chinese Journal of Integrated Traditional and Western Medicine, vol. 18, no. 1, pp. 35-37, 1998. 


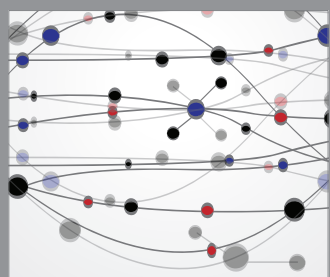

The Scientific World Journal
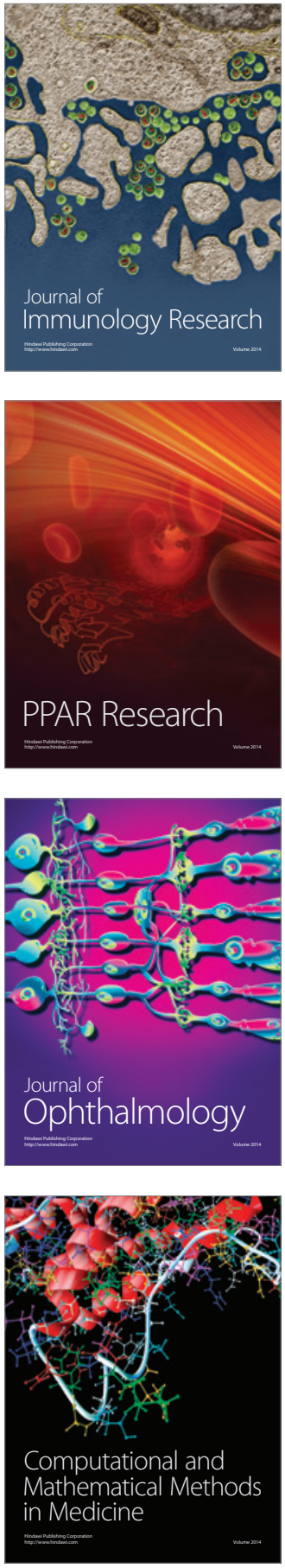

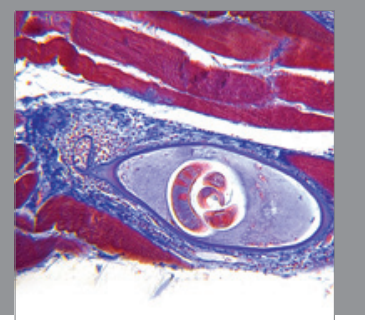

Gastroenterology

Research and Practice
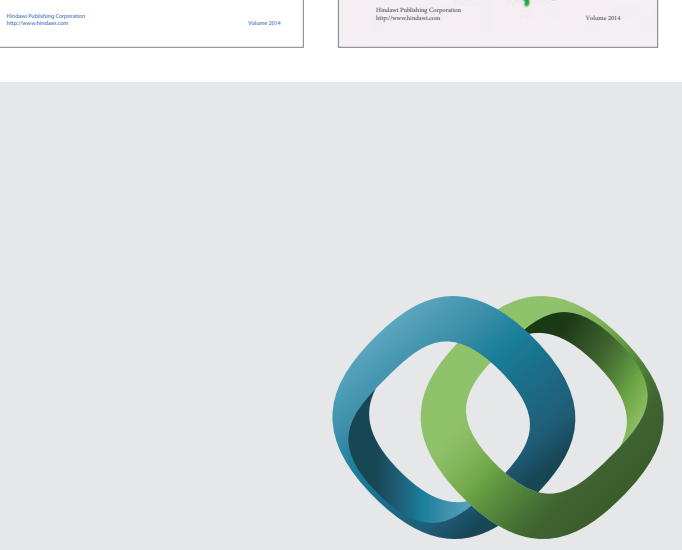

\section{Hindawi}

Submit your manuscripts at

http://www.hindawi.com
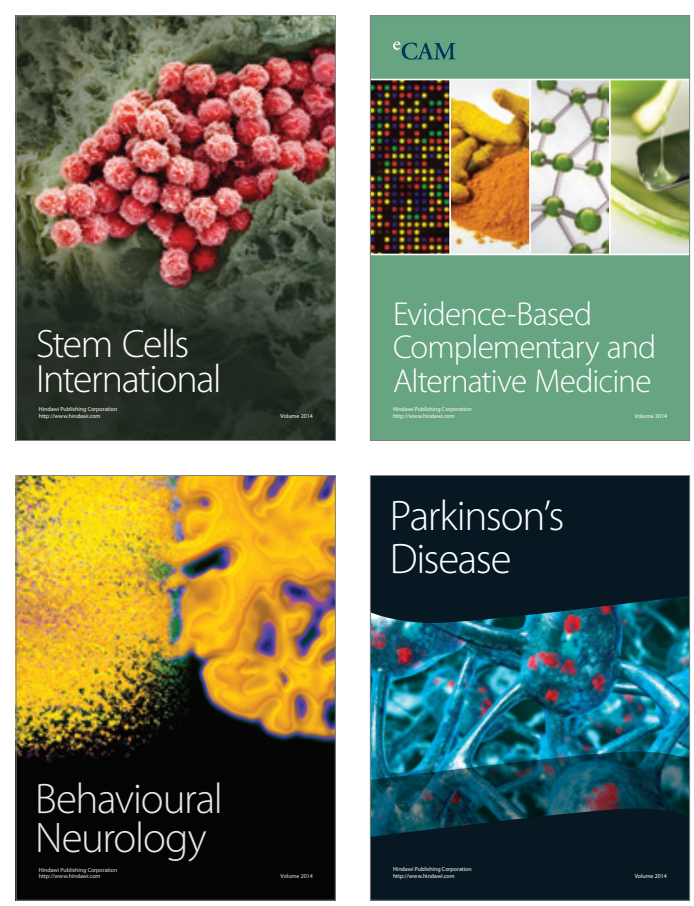

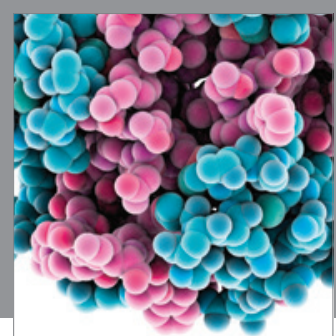

Journal of
Diabetes Research

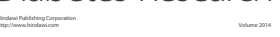

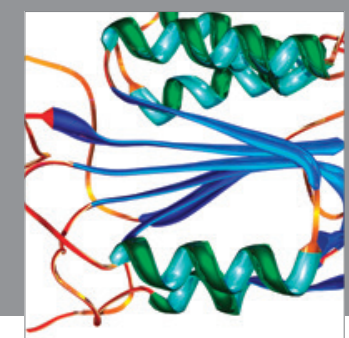

Disease Markers
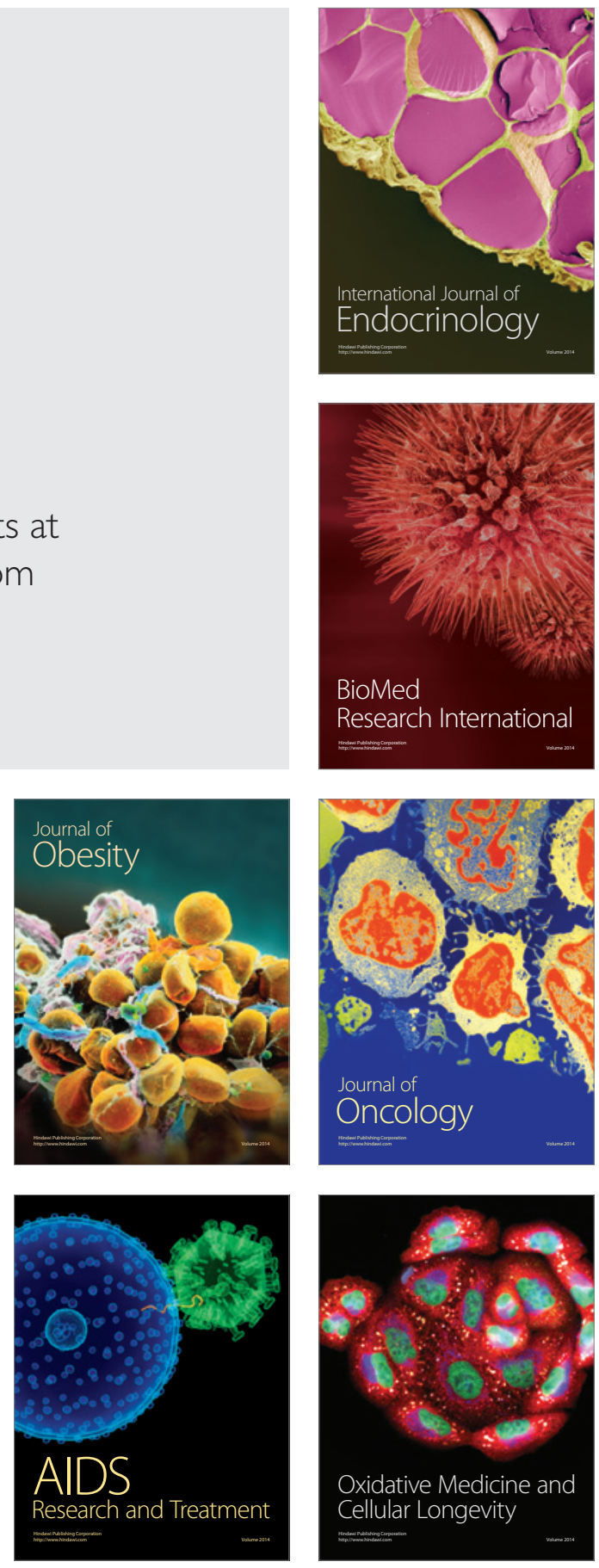